\title{
Bio-activity in Flowers of Sarcostemma viminale (L.) R.Br.- An Endangered Medicinal Plant from Thar Desert of Rajasthan (India)
}

\author{
Sunita Arora ${ }^{1 *}$ Sonam Meena ${ }^{2}$
}

\section{Sunita Arora ${ }^{1 *}$ Sonam Meena ${ }^{2}$}

'Professor, Department of Botany, Jai Narain Vyas University, Jodhpur, Rajasthan, INDIA.

${ }^{2}$ Research Scholar, Department of Botany, Jai Narain Vyas University, Jodhpur, Rajasthan, INDIA.

\section{Correspondence}

\section{Prof. Sunita Arora}

Professor, Department of Botany, Jai Narain Vyas University, Jodhpur, Rajasthan, INDIA.

Phone no : 9414319675

E-mail: jnvusunitarora@gmail.com

\section{History}

- Submission Date: 03-03-2018;

- Review completed: 18-04-2018;

- Accepted Date: 22-06-2018

DOI : 10.5530/pj.2018.5.146

Article Available online http://www.phcogj.com/v10/i5

\section{Copyright}

(c) 2018 Phcog.Net. This is an openaccess article distributed under the terms of the Creative Commons Attribution 4.0 International license.

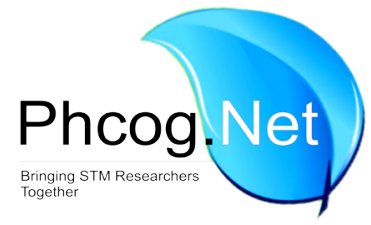

\begin{abstract}
Background: Sarcostemma viminale (L.) R.Br. (Asclepiadaceae), an endangered medicinal plant distributed in various habitats in semi-arid region of Thar Desert of Rajasthan. Present study is focused on the extraction of bioactive compounds from the flowers of this plant by Gas chromatography mass spectrometry (GC-MS) using Methanol and chloroform as solvents. Methods: Flowers were collected from hilly and stony regions from xeric and harsh conditions of Indian Thar Desert of Rajasthan, during the month of July-September. The phytochemical compounds were investigated using Perkin-Elmer Gas Chromatography-Mass Spectrometry, while the mass spectra of the compounds found in the extract were matched with the National Institute of Standards and Technology library. Result: Maximum \% area is found for 24-Norursa-3, 12-diene is present in maximum amount $(26.25 \%)$ with retention time (RT) $=39.441 \mathrm{~min}$, followed by Tetracontane $(20.68 \%)$ with $\mathrm{RT}=30.275 \mathrm{~min}$ in the methanolic extract. Lup-20(29)-en-3-ol, acetate, (3.beta.)- is present in maximum amount (35.70\%) with retention time $(R T)=38.569 \mathrm{~min}$, followed by Tetracontane $(15.24 \%)$ with $R T=29.678 \mathrm{~min}$ in the chloroform extract of flowers of Sarcostemma viminale (L.) R.Br. Conclusion: Flowers of Sarcostemma viminale (L.) R.Br. shows important pinpoint pharmacological activity. These bio-active constituents can be used by pharmaceutical or other drug designing industry to find a novel drug and pharmacologically active constituents justifying the use of this plant to treat many ailments.

Key words: Asclepiadeaceae, Sarcostemma viminale (L.) R.Br., GC-MS, Methanol, Chloroform, Phytochemicals, Retention time (RT), Hexatriacontane.
\end{abstract}

\section{INTRODUCTION}

India is the largest producer of medicinal herbs and is appropriately called the botanical garden of the world. ${ }^{1}$ Plants play a significant role in the prevention and treatment of diseases and can even prevent and reduce the adverse effects of conventional treatments. ${ }^{2}$ They can be a source of chemical compounds of biological and pharmacological importance. History reveals that plants are sources of successful drugs, and will continuously be important for screening of new lead compounds ${ }^{3}$ an essential part in the investigation of plant is the identification of the biologically active compounds present in plant leading to further biological and pharmacological studies. ${ }^{4-7}$ Plants are capable of synthesizing an overwhelming variety of low-molecular weight organic compounds called secondary metabolites, usually with unique and complex structures. Many metabolites have been found to possess interesting biological activities and find applications, such as pharmaceuticals, insecticides, dyes, flavors and fragrances. Plants used for traditional medicine contain a wide range of substances that can be used to treat chronic as well as infectious diseases. ${ }^{8}$ Plants are a rich source of secondary metabolites with interesting biological activities. In general, these secondary metabolites are an important source with a variety of structural arrangements and properties. ${ }^{9}$ The secondary metabolites of plants provide numerous biologically active products which has been used extensively as drugs, foods, additives, flavors, insecticides, colorants, fragrances and chemicals. ${ }^{10}$

The family Asclepiadaceae was previously ranked as family and now it is treated as a subfamily of Apocynaceae. This view was also upheld by the Angiosperm Phylogeny Group. ${ }^{11-12}$ It is comprised of approximate 130 genera and 2,000 species tropical as well as subtropical, mostly shrubs, often twining or perennial herbs. ${ }^{13}$ Sarcostemma is commonly known as moon plant and in veda it is known as "soma." It is a remarkably glabrous, vigorously tangling scrambler and climber, which can produce voluminous plants. ${ }^{14-15}$ Sarcostemma is a genus of at least 35 species of flowering plants. The plants are well adapted to xeric conditions of Thar Desert. It inhabits dry and rocky areas on hills. The soft stem is filled with milky white latex that is poisonous and caustic in some species, so often named as caustic vine. The flowers have a ring of thick tissue at the base which extends into hollow spherical appendages within the corolla. ${ }^{16}$ It is more branched, leaves are either absent or highly reduced, grows always in association 
with Euphorbia caducifolia. ${ }^{17}$ The root is used to cure snake bite and taken as an infusion in dog bite cases in Thar Desert. ${ }^{18}$ The dry stem is used as emetic and stem juice mixed with water is given in rheumatism, arthritis, joints pain, ${ }^{19}$ and stem is also used to cure bone fracture. ${ }^{20}$

In the last few years, gas chromatography mass spectrometry (GC-MS) has become firmly established as a key technological platform for secondary metabolite profiling in both plant and non-plant species. ${ }^{21-23}$ Interpretation on mass spectrum GC-MS was conducted using the database of National Institute Standard and Technology (NIST) having more than 62,000 patterns. The spectrum of the unknown component was compared with the spectrum of the known components stored in the NIST library. ${ }^{24}$ Plant-derived bioactive phyto compounds can be used for herbal drug formulations. ${ }^{25}$

\section{MATERIAL AND METHODS}

\section{Collection and extraction of plant material}

Fresh flowers of S. viminale (L.) R. Br. were collected from hilly and stony regions of Jodhpur district of Rajasthan (India) in the month of June- August. The specimen authentication and botanical identification was done by Botanical Survey of India, Jod hpur (Rajasthan). The flowers were thoroughly washed with tap water followed by distilled water, dried under shade for 25 days and ground into fine powder. After sieving the powder was transferred to airtight polyethylene zipper bags, labeled and stored till further use. $2 \mathrm{~g}$ of coarse powder was transferred to round bottom flask. $200 \mathrm{ml}$ of solvent was added to each flask containing crude powdered plant material. Hot extraction method using soxhlet apparatus was followed with methanol and chloroform as solvent. The solution was then boiled at $60-70^{\circ} \mathrm{C}$ for $18 \mathrm{~h}$ on water bath, filtered, evaporated to dryness and final residue was then subjected to GC-MS analysis.

\section{GC-MS analysis}

The gas chromatography-mass spectroscopy (GC-MS) analysis was performed at Advanced Instrumentation Research Facility (AIRF), Jawaharlal Nehru University, New Delhi, India. Gas chromatographyMass spectrometry (GC-MS) analysis of the extracts was performed using a GC-MS (Model; QP 2010ultra-series, Shimadzu, Tokyo, Japan) equipped with thermal desorption system TD 20. Injection Mode: Split, Flow Control Mode: Linear Velocity, Pressure: $81.9 \mathrm{kPa}$, Linear Velocity: $40.5 \mathrm{~cm} / \mathrm{sec}$, Purge Flow: $3.0 \mathrm{ml} / \mathrm{min}$, Split Ratio: 50.0. For GC-MS detection [GC-2010], For GC-MS detection and electron ionization system with ionizing energy of 70ev was used. Helium gas (99.99\%) was used as the carrier gas at constant flow rate $1 \mathrm{ml} / \mathrm{min}$ in the split mode (10:1) and an injection volume of $2 \mu$ of chloroform solution of different plant part sample was injected into the column with the injector temperature $260^{\circ} \mathrm{C}$, ion-source temperature $230^{\circ} \mathrm{C}$. column oven temperature was maintained at $80^{\circ} \mathrm{C}$, Pressure was maintained at $81.9 \mathrm{kPa}$. Equilibrium time was $0.5 \mathrm{~min}$. start $\mathrm{m} / \mathrm{z}$ ratio was 40.00 and it ended at 650.00 . The relative \% amount of each component was calculated by comparing its average peak area to the total area, software adopted to handle mass spectra and chromatograms was a Turbomass. The relative percentage of each extract constituents was expressed as percentage with peak area.

\section{RESULT AND DISCUSSION}

Medicinal plants besides being therapeutic agents are also a large source of information for a wide variety of chemical constituents which could be developed as drugs with precise selectivity. These are the reservoirs of potentially useful chemical compounds which could serve as newer leads and clues for modern drug design. ${ }^{26}$

GC-MS chromatogram of the methanolic and chloroform extract of flowers of Sarcostemma viminale (L.) R.Br. showed 64 and 69 peaks

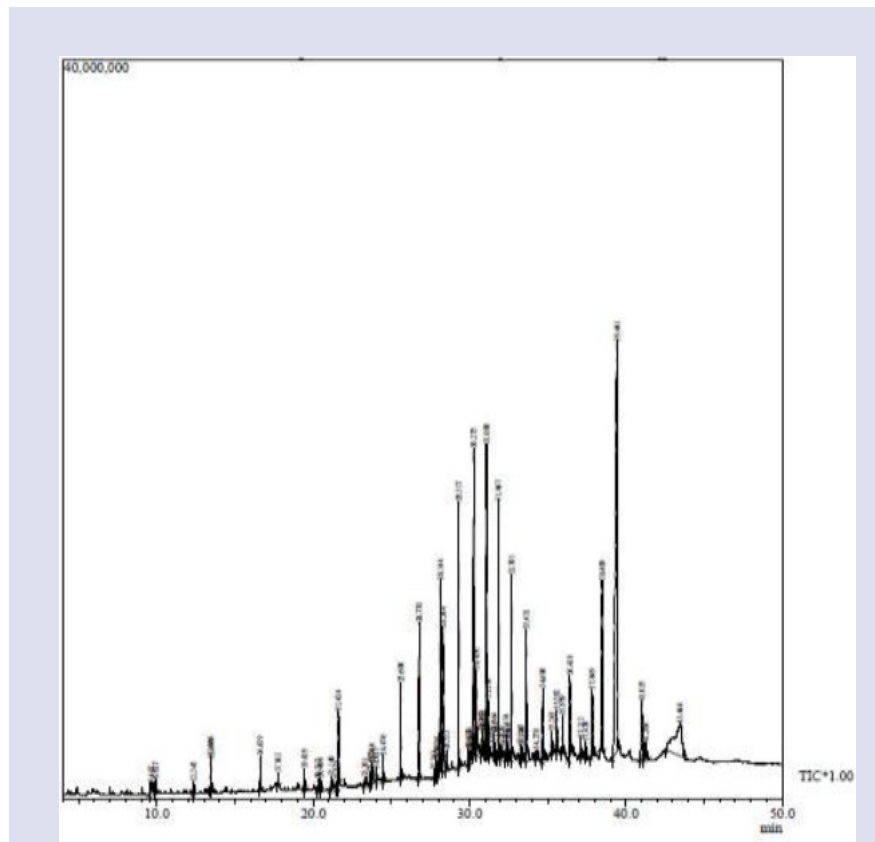

Figure 1: GC-MS chromatogram of the methanolic extractof flower of Sarcostemma viminale.

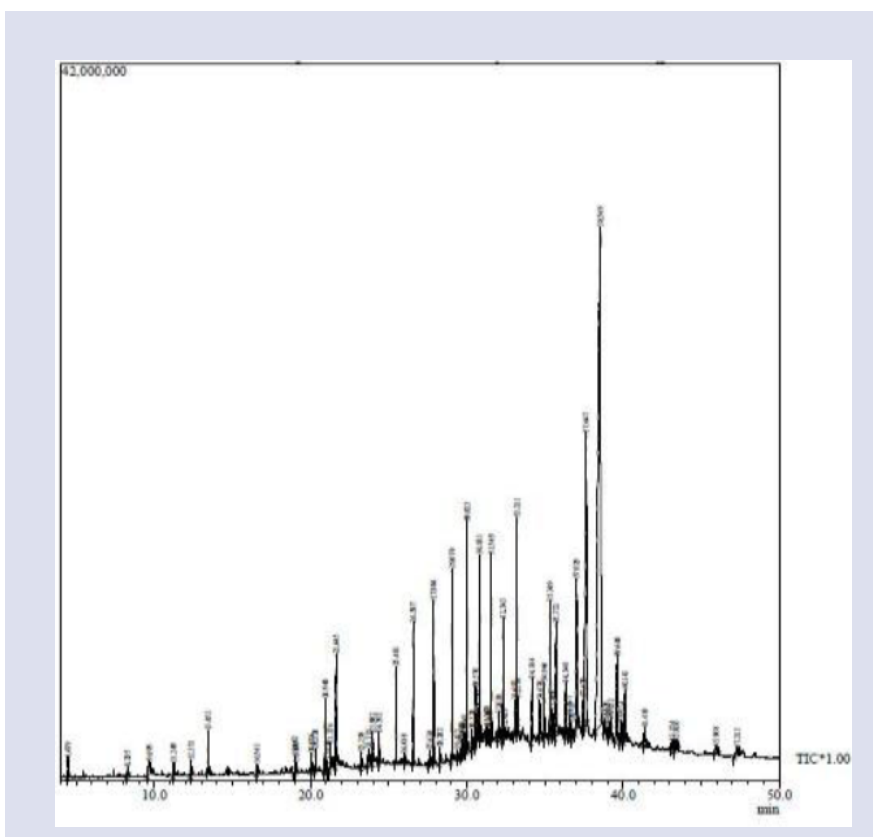

Figure 2: GC-MS chromatogram of the chloroform extract of flower of Sarcostemma viminale.

(Figure 1,2) indicating the presence of 50 and 52 compounds respectively. Confirmation of their presence was based on retention time (RT), peak area, molecular formula, concentration (\%), and molecular weight (Tables 1,2).

24-Norursa-3,12-diene is present in maximum amount (26.25\%) with retention time $(\mathrm{RT})=39.441 \mathrm{~min}$, followed by Tetracontane $(20.68 \%)$ with $\mathrm{RT}=30.275 \mathrm{~min}$ and ${ }^{1} \mathrm{H}$-indene, 1-hexadecyl-2,3-dihydro- is present in minimum amount $(0.03 \%)$ with $\mathrm{RT}=30.197 \mathrm{~min}$, followed by 
Table 1: Bio-activity of compounds in the methanolic extract of flower of Sarcostemma viminale (L.) R.Br.

\begin{tabular}{|c|c|c|c|}
\hline RT (min) & Compound Name & Area \% & Biological Activity \\
\hline 9.647 & Benzoic acid & 0.59 & $\begin{array}{l}\text { Used as an expectorant and fungal skin diseases, Analgesic, Food } \\
\text { Industry, Antifungal properties }\end{array}$ \\
\hline 9.927 & Naphthalene & 0.27 & Antiseptic, Carcinogenic \\
\hline 13.477 & 1-Pentadecene & 0.33 & Antitumor \\
\hline 16.619 & 1-Heptadecene & 0.42 & $\begin{array}{l}\text { Artificial ripening of fruits, metabolism of aromatic compounds in } \\
\text { animals, antimicrobial }\end{array}$ \\
\hline 19.439 & 1-Octadecene & 0.27 & Finishing agent, Intermediates, Lubricants and Lubricant additives \\
\hline 20.317 & 1,2-Benzenedicarboxilic acid,bis(2-methylpropyl) ester & 0.16 & Antimicrobial,Antifouling \\
\hline 20.490 & 8-Octadecanone & 0.15 & Antimicrobial activity \\
\hline 21.140 & Hexadecanoic acid, methyl ester & 0.19 & $\begin{array}{l}\text { Antioxidant, hypocholesterolenic, antiandrogenic, flavour, } \\
\text { nematicide, hemolytic5-alpha reductase inhibitor }\end{array}$ \\
\hline
\end{tabular}

Table 2: Bio-activity of compounds in the chloroform extract of flower of Sarcostemma viminale (L.) R.Br.

\begin{tabular}{|c|c|c|c|}
\hline $\mathrm{RT}(\mathrm{min})$ & Compound Name & Area\% & Biological Activity \\
\hline 9.699 & Benzoic acid & 0.60 & $\begin{array}{c}\text { Used as an expectorant and fungal skin diseases, Analgesic, } \\
\text { Food Industry, Antifungal properties }\end{array}$ \\
\hline 13.452 & 2-Furancarboxaldehyde, -5-(hydroxymethyl)- & 0.49 & Antimicrobial \\
\hline 16.561 & Diethyl phthalate & 0.11 & Estrogenic activity, Antimicrobial, Plasticizer, Antioxidant \\
\hline 19.002 & Tetradecanoic acid & 0.21 & $\begin{array}{c}\text { Antioxidant, Cancer preventive, Nematicide, Lubricant, } \\
\text { Hypocholesterolemic }\end{array}$ \\
\hline 20.076 & 2-Pentadecanone,6,10,14-trimethyl- & 0.35 & Antibacterial activity \\
\hline 20.320 & 1,2-Benzenedicarboxilic acid, bis(2-methylpropyl) ester & 0.25 & Antimicrobial,Antifouling \\
\hline 20.940 & 7,9-Di-tert-butyl-1-oxaspiro(4,5)deca-6,9-diene-2,8-dione & 0.83 & Antimicrobial activity \\
\hline 21.645 & n-Hexadecanoic acid & 2.25 & $\begin{array}{c}\text { Antifungal, Antioxidant, Hypocholesterolemic Nematicide, } \\
\text { Anti-Androgenic Flavour, Haemolytic 5-Alphareductase } \\
\text { Inhibitor, Potent Antimicrobial Agent, Antimalarial and } \\
\text { Antifungal }\end{array}$ \\
\hline 23.258 & Heneicosane & 1.61 & Antibacterial, Oviposition attractant pheromone \\
\hline
\end{tabular}

1,4-Dioxane-2,5-dione, 3,3,6,6-trtramethyl- (0.05\%) with RT=32.320 in the methanolic extract.

Lup-20(29)-en-3-ol, acetate, (3.beta.)- is present in maximum amount (35.70\%) with retention time $(\mathrm{RT})=38.569 \mathrm{~min}$, followed by Tetracontane (15.24\%) with RT=29.678 min and Nonanal (0.09\%), 4,8,12,16-Tetramethylheptadecan-4-olide (0.09\%), Hexacosane $(0.09 \%)$ were presentin minimum and same amount with $\mathrm{RT}=8.295,26.010$ and $31.287 \mathrm{~min}$ respectively followed by Diethyl phthalate, Henicosanal $(0.11 \%)$ with $\mathrm{RT}=16.561,29.417 \mathrm{~min}$ respectively inthe chloroform extract.

The gas chromatogram shows the relative concentrations of various compounds getting eluted as a function of retention time. The peak indicates relative concentration of the components present in the extract. The mass spectrometer analyzes the compounds eluted at different time that identify the nature and structure of the compounds. The large fraction gets dissected into smaller compounds giving rise to appearance of peaks at different $\mathrm{m} / \mathrm{z}$ (mass to charge) ratio. These mass spectra are fingerprint of that compounds which can be identified from the data library.

\section{CONCLUSION}

The authors are first to report the presence of some important bioactive phytoconstituents from flowers of this plant using GC-MS analysis. The study using solvent-linked polarity and extraction potentiality is the best tool for extraction of bioactive compounds. Application of GC-MS includes environmental analysis, drug detection and identification of unknown samples. The presence of various bioactive compounds in the flowers confirms the application of Sarcostemma viminale (L.) R.Br. used for treating various ailments by traditional practitioner's andby pharmaceutical companies to formulate novel drugs and improve the health status. This plant being endangered requires prime attention for conservation before it is being used for medical trials. More research is required in other aspects of this plant.

\section{ACKNOWLEDGEMENT}

Authors express sincere thanks to Prof. P.K. Kasera for providing academic support and the CAS Department of Botany J.N.V. University, Jodhpur (Rajasthan) for providing research facilities, infrastructure and 
technical support. I am also thankful to University Grants Commission (UGC), New Delhi for providing financial support.

\section{CONFLICT OF INTEREST}

Authors declares that they have no conflict of interest.

\section{ABBREVIATIONS}

\section{L.: Linnaeus; R.Br.: Robert Brown.}

\section{REFERENCES}

1. Ahmedull M, Nayar MP. Red Data Book for Indian plants. Botanical Survey of India. 1999;4.

2. Bachrach ZY. Contribution of selected medicinal plants for cancer prevention and therapy. Acta Facultatis Medicae Naissensis. 2012;29(3):117-23.

3. Atanasov AG, Waltenberger B, Pferschy-Wenzig EM, Linder T, Wawrosch C, Uhrin P. Discovery and resupply of pharmacologically active plant-derived natural products: A review. Biotechnol Adv. 2015;33(8):1582-614.

4. Guo F, Feng L, Huang $C$, Ding $H$, Zhang $X$, Wang $Z$, et al. Phenylflavone derivatives from Broussonetia papyrifera inhibit the growth of breast cancer cells in vitro and in vivo. Phytochem Letters. 2013;6(3):331-6.

5. Momin MA, Bellah SF, Rahman SM, Rahman AA, Murshid GM, Emran TB. Phytopharmacological evaluation of ethanol extract of Sida cordifolia L. Roots. Asian Pac J Trop Biomed. 2014;4(1):18-24.

6. Farid MM, Hussein SR, Ibrahim LF, Desouky MA, Elsayed AM, Oqlah AA. Cytotoxic activity and phytochemical analysis of Arum palaestinum Boiss. Asian Pac J Trop Biomed. 2015;5(11):944-7.

7. Arora S, Meena S. Qualitative premilinary phytochemical screening and GC-MS analysis of root of Sarcostemma viminale (L.) R Br. An endangered plant. Int J Pharm Res Bio-Sci. 2016;5(2):89-100.

8. Duraipandiyan $\mathrm{V}$, Ayyanar M, Ignacimuthu S. Antimicrobial activity of some ethnomedicinal plants used by Paliyar tribe from Tamil Nadu, India. BMC Complement Altern Med. 2006;6(35):1-7.

9. De-Fatima A, Modolo LV, Conegero LS, Pilli RA, Ferreira CV, Kohn LK, et al Lactones and their derivatives: Biological activities, mechanisms of action and potential leads for drug design. Curr Med Chem. 2006;13(28):3371-84.

10. Koduru S, Grierson DS, Afolayan A. Antimicrobial activity of Solanum aculeastrum Pharm Biol. 2006;44(4):283-6.
11. Angiosperm Phylogeny Group. An update of Angiosperm Phylogeny Group (AGP) classification for orders and families of flowering plants: APG II. Bot. J Linn Soc. 2003;141(4):399-436.

12. Angiosperm Phylogeny Group. An update of the Angiosperm Phylogeny Group Classification for the orders and families of flowering plants. Bot J Linn Soc. 2009;161(2):105-21.

13. Indhumathi D, Kalvimoorthi. Pharmacognostic preliminary phytochemical and anti-microbial activity on the whole plant of Sarcostemma secomone (L.) Bennet. Int J Pharm Sci Rev Res. 2010;1(2):49-55.

14. Meve U, Lied-Schumann S. Taxonomic dissolution of Sarcostemma (Apocynaceae: Asclepiadoideae). Kew Bull. 2012;67(4):751-8.

15. Arora S, Meena S. Qualitative phytochemical screening and GC-MS analysis of Sarcostemma viminale (L.) RBr. An endangered plant from Thar Desert. Ad Plant Sci. 2016;29(2):279-82

16. GRIN. Species records of Sarcostemma. Germplasm Resources Information Network. United States Department of Agriculture. 2011

17. Shetty BV, Singh V. Flora of Rajasthan. Botanical Survey of India, Culcutta 1993;3:861-1246.

18. Mohammed S, Kasera PK, Shukla JK. Unexploited plants of potential medicinal value from the Indian Thar desert. Nat Prod Rad. 2004;3(2):69-74.

19. Ray S, Sheikh M, Mishra S. Ethanomedicinal plants used by tribals of East Nimar Madhya Pradesh. Indian J Trad Knowle. 2011;10(2):367-71.

20. Patil DA. Indian ethnomedicines: Origins in the perspective of doctrine of signature. Life Sci Leafl. 2012;1:6-15.

21. Robertson DG. Metabonomics in toxicology: A review. Toxicol Sci. 2005; 85(2):809-22.

22. Fernie AR, Trethewey RN, Krotzky AJ, Willmitzer L. Metabolite profiling: From diagnostics to systems biology. Nat Rev Mol Cell Biol. 2004;5(9):763-9.

23. Kell DB, Brown M, Davey HM, Dunn WB, Spasic I, Oliver SG. Metabolic footprinting and systems biology: The medium is the message. Nat Rev Microbiol.2005;3(7):557-65.

24. Ammal RM, Stella Bai GV. GC-MS Determination of Bioactive Constituents of Heliotropium indicum Leaf. J Med plants Stud. 2013;1(6):30-3.

25. Arora S, Meena S, Kumar G. Gas Chromatography-Mass Spectrometry analysis of an endangered medicinal plant, Sarcostemma viminale (L.) $\mathrm{R} \mathrm{Br}$. from Thar Desert, Rajasthan (India). Asian J Pharm Clin Res. 2017;10(9):210-3.

26. Vijyalakshmi R, Ravindran R. Preliminary comparative phytochemical screening of root extracts of Diospyrus ferrca (Wild.) Bakh and Arvalanata (L.) Juss. Ex Schultes. Asian J Plant Sci Res. 2012;2(5):581-7.

\section{GRAPHICAL ABSTRACT}

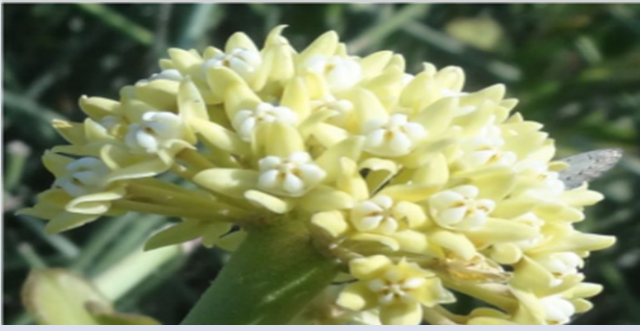

\section{SUMMARY}

Conservation of Sarcostemma viminale (L.) R.Br. is required the most on priority basis as so many valuable bioactive compounds can be extracted from whole plant. Flowers are equally important and they are produced in large amount. Whole plant can be used in treating various ailments. Ethics and legal procedures need further research.

\section{ABOUT AUTHORS}

Prof. Sunita Arora (Corresponding author) Professor, Department of Botany, Jai Narain Vyas University, Jodhpur, Rajasthan, INDIA.

Sonam Meena Research Scholar, Department of Botany, Jai Narain Vyas University, Jodhpur, Rajasthan, INDIA. 